\title{
THE ESTIMATION OF SUBSURFACE STRUCTURE WITHIN GEOTHERMAL MANIFESTATION AREA AS AN OUTFLOW ZONE USING GEOELECTRICAL RESISTIVITY METHOD IN TEGAL, JAWA TENGAH
}

\author{
Hangga Novian Adi Putra ${ }^{1}$, Wahyudi ${ }^{2}$ \\ ${ }^{1,2}$ Department of Physics, Faculty of Mathematical and Natural Sciences, \\ Universitas Gadjah Mada \\ Email : hangganovian68@gmail.com
}

\begin{abstract}
Indonesia is one of the country having a lot of geothermal fields potentially used as a source of energy. For example, Java island is noted to have almost 57 geothermal fields. One of those geothermal fields which is rarely studied is Guci geothermal field. Hence, there was conducted a research to investigate the subsurface image and geothermal system in Guci geothermal field based on resistivity data. The research in Guci geothermal field was carried out using geoelectrical method. Resistivity geoelectrical research used two configurations, namely dipole-dipole and schlumberger. Data acquisitions for dipole-dipole configuration was done in two lines, 500 metres spread for each line. Whereas the acquisitions for schlumberger configuration was done in four points, 200-250 metres spread for each point. Research result showed that the area of geothermal manifestation in Guci consist of top soil layer, sandstone, andesite, and a fluids-containing layer. A fluids-containing layer is estimated to be related to geothermal manifestation in Guci and is a fault zone. Fault is estimated to be a normal fault and lies in 20 metres depth. Fault within geothermal manifestation area in Guci has a role as the pathway of hot-fluid out to the surface which forms a manifestation.
\end{abstract}

Keywords : Geoelectric, Resistivity, Schlumberger, Dipole-dipole, Guci

\section{A. INTRODUCTION}

Indonesia is one of the country having a lot of geothermal fields in the world. For example, Java island is noted to have almost 57 geothermal fields (as in Figure 1). One of those geothermal fields which is rarely studied is Guci geothermal field.

Guci Geothermal Field is administratively located in Bumijawa sub-district and Bojong sub-district, Tegal regency, Central Java province and is located in the northern leg of the
Slamet volcano. The existence of geothermal potential in this area is characterized by the presence of geothermal manifestations in the form of springs / hot water pools located in the Guci area. The area of the Guci geothermal field is 14,360 hectares covering the Rembul village area of Bojong sub-district and Guci village of Bumijawa sub-district with an estimated potential of 55 MW (Utama et al., 2012). 


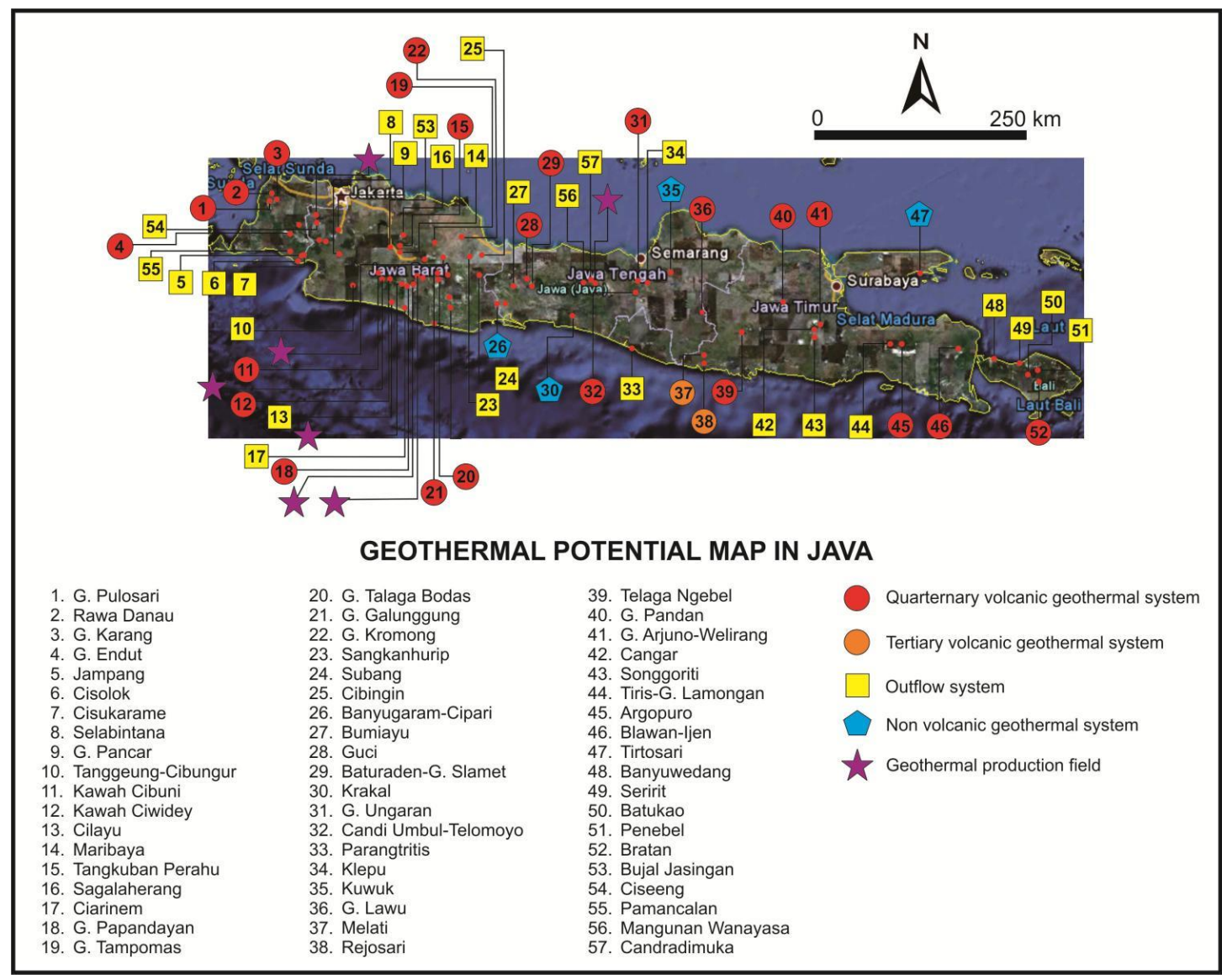

Figure 1. Map of the distribution of geothermal fields on the island of Java

Researches in the Guci geothermal field area are still carried out regionally covering the Slamet volcano area. Information about the components of the geothermal system in the Gucipun area is still very limited. Therefore, research was conducted to find out more complete Guci geothermal systems. In this study discussed is information about the geological structure can be in the form of faults in the geothermal area of Guci. The method used in this study is the resistivity Geoelectric method.

Geoelectric resistivity method is useful to determine changes in type resistance both vertically (sounding) and horizontally (mapping). The Geoelectric Method chosen in this study is a Geoelectric method with Dipole-Dipole and Schlumberger configurations that will produce two-dimensional and onedimensional resistivity data. Geoelectric methods in particular the Dipole-Dipole configuration has advantages such as being very sensitive to lateral variations so that it is suitable for identifying vertical structures such as faults and dike (Aminu et al., 2014). Besides this research with Geoelectric method is also 
still very rarely done in the Guci geothermal field.

\section{Research using Geoelectric} methods in geothermal fields This jar is expected to provide an overview of the surface of the surface in the Guci geothermal field, Tegal, Central Java. This research will also be expected to provide more detailed information about the existence of faults in Guci geothermal areas. This research can complement and support information that already existed before so that we can get an estimate of the more complete and detailed description of the Guci geothermal system.

\section{B. MATERIALS AND METHODS}

The research was carried out by following the following stages which can be seen in the research flow chart as presented in Figure 2.

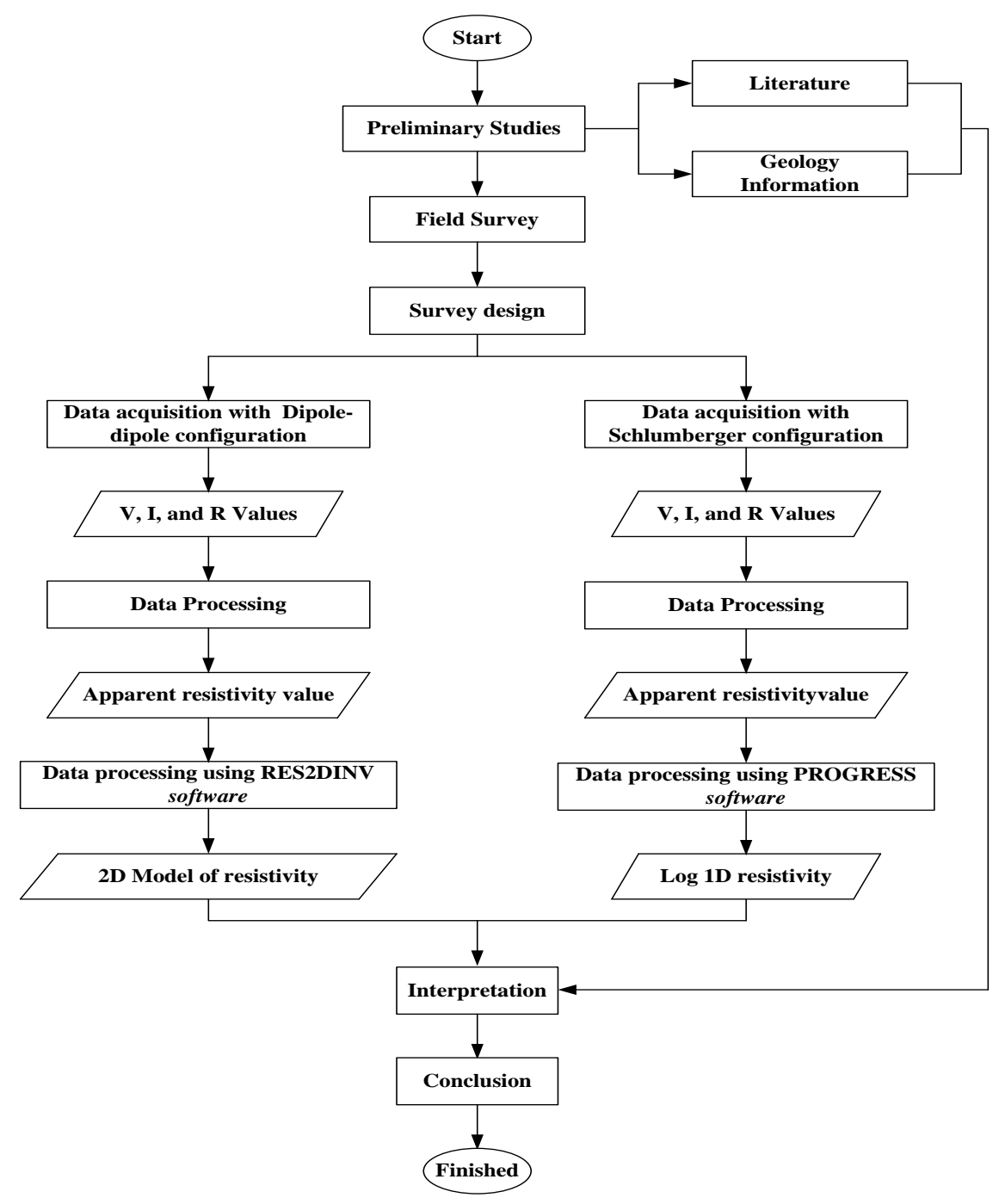

Figure 2. Research Flow Chart with Geoelectric Method 
In practice, the geoelectric method injects DC electric current (Direct Current) into the ground. Electric current injection uses two pieces electrode current $\mathrm{C}_{1}$ and $\mathrm{C}_{2}$ which is stuck into the ground at a certain distance. The farther the distance between $\mathrm{C}_{1}$ and $\mathrm{C}_{2}$ will cause the flow of electric current can penetrate deeper rock layers The current will be measured using potential electrode $\mathrm{P}_{1}$ dan $\mathrm{P}_{2}$ (Broto \& Afifah, 2008). This four electrode system has many types of arrays such as Schlumberger, Wenner and, Dipole-Dipole. The Geoelectric Method chosen in this study is a Geoelectric method with Dipole-Dipole and Schlumberger configurations. The vertical resistivity sounding is based on the concept of a homogeneous, isotropic, layered horizontal earth model, where the subsurface is restricted to a number of horizontal layers, the linear filter method is commonly used to calculate the true resistivity from the measured apparent resistivity (Khalil \& Santos, 2013).

Before conducting the research, a survey design was made in the Guci geothermal field. The number of trajectories in the study was only 2 lines of 500 meters each for Dipole-Dipole configuration and 4 measurement points for Schlumberger configuration. The research survey design can be seen in Figure 3.

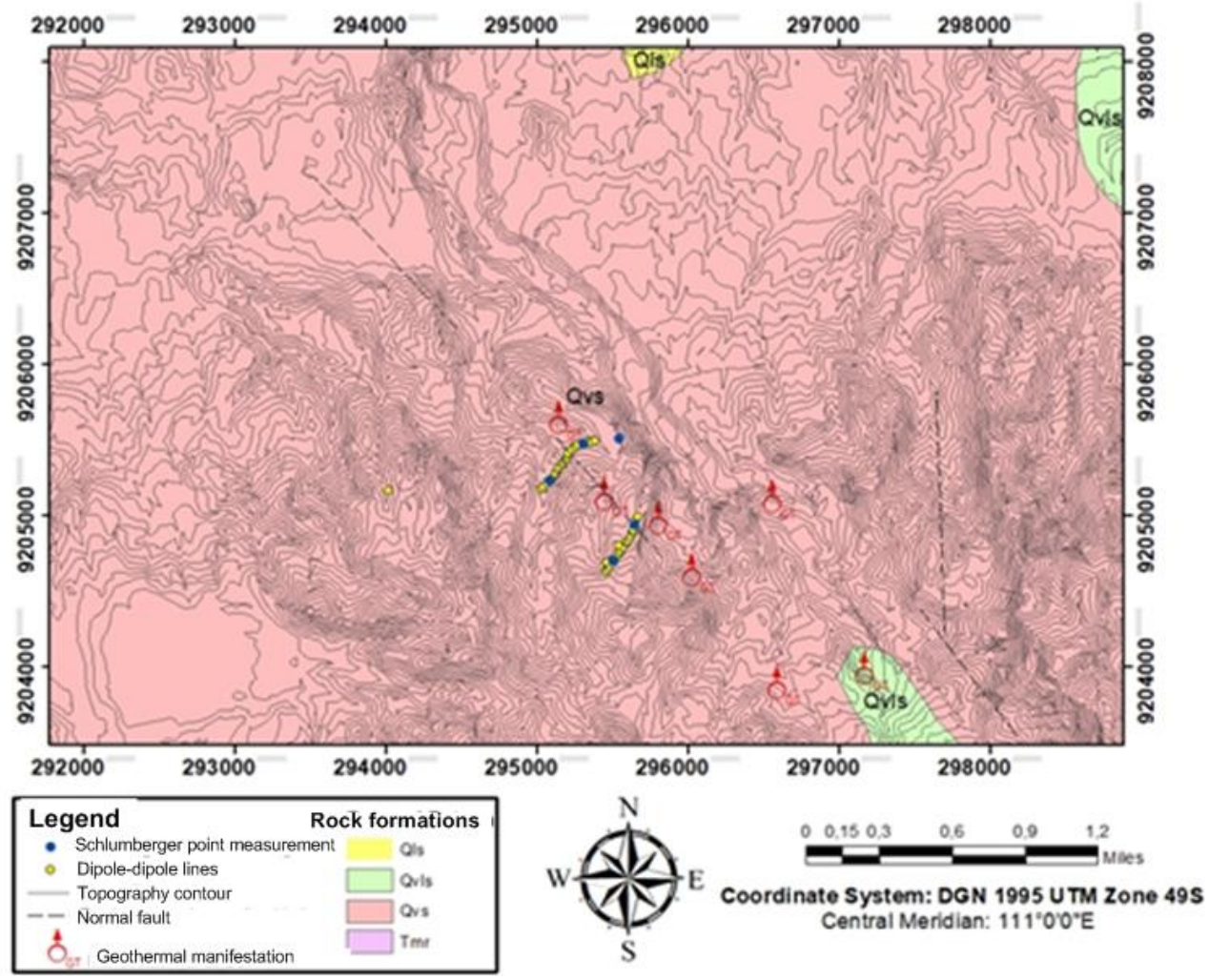

Figure 3. Map of Research Survey Design 


\section{RESULTS AND DISCUSSION}

Geoelectric data with Dipoledipole configuration are processed using RES2DINV software which produces a two-dimensional resistivity section. Whereas Schlumberger configuration is processed using PROGRESS software which produces one-dimensional resistivity logs. The two-dimensional resistivity cross section is analyzed by looking at the resistivity value in each path, then compared with the rock resistivity value based on the existing references. In addition, it will also be correlated with one-dimensional resitivity $\log$ as supporting data so that it will get a subsurface model of Guci geothermal manifestation area.

\section{Line 1}

Two-dimensional resistivity cross section of the Dipole-dipole configuration that is processed using RES2DINV software while for Schlumberger configuration is processed with PROGRESS software. The results of the correlation between the twodimensional resistivity section with onedimensional resistivity log can be seen in Figure 4.

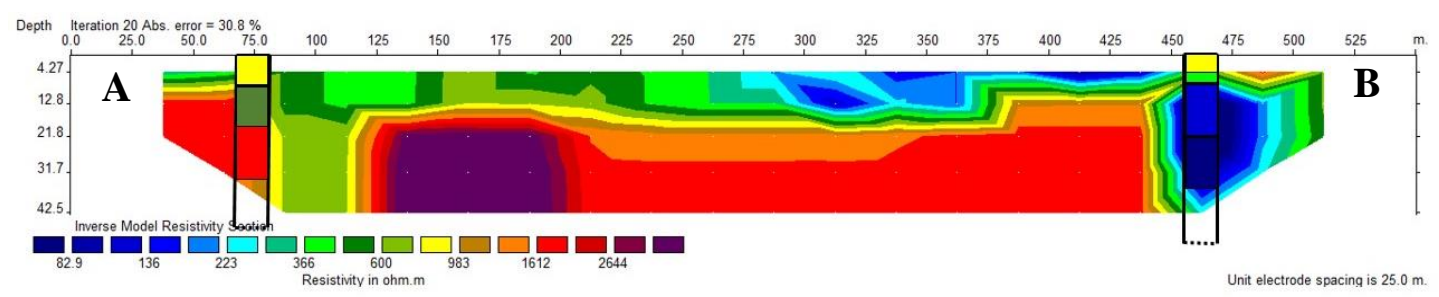

Figure 4. Correlation between line 1 Dipole-dipole with point VES 1 and VES 2 Schlumberger

The correlation between twodimensional reactivity section with onedimensional resistivity $\log$ is done to support the interpretation. In Figure 3.1, there is a suitability of the range of resistivity values between twodimensional resistivity section with onedimensional resistivity log. This onedimensional resistivity $\log$ also acts as supporting data so that the interpretations that have been made are better and more accurate. By combining information from a two-dimensional resistivity section and one-dimensional resistivity log, the results of interpretation of subsurface models on line one can be seen in Table 1 .

The resistivity cross section obtained can be given topographic effects so that it can facilitate interpretation. The resistivity crossing on the one path with topographic effects can 
be seen in Figure 5. In addition, if the presence of geothermal manifestations is projected on the resistivity cross section of one feeding path, the presence of geothermal manifestations is at the 450th meter.

Table 1. Interpretation of Resistivity value of line one

\begin{tabular}{|c|l|l|}
\hline Num. & Resistivity Value $\mathbf{( \Omega m})$ & Name of Layer \\
\hline 1. & $82-136$ & Sandstone layer containing fluid \\
\hline 2. & $366-600$ & Sandstone \\
\hline 3. & $916,89-959,95$ & Top Soil \\
\hline 4. & $1612-2644$ & Volcanic stones \\
\hline
\end{tabular}

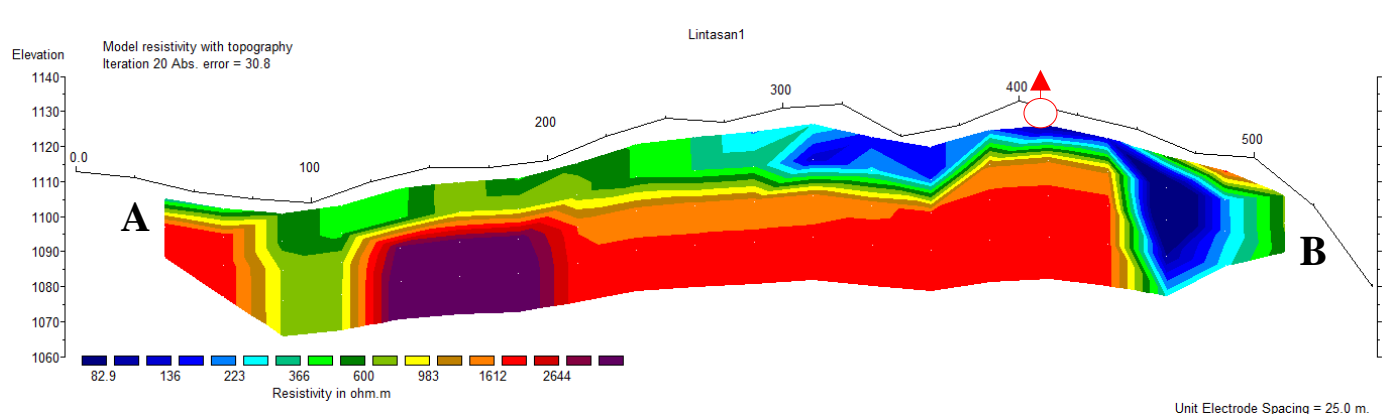

Figure 5. Two-dimensional resistivity cross section with topographic effects on line 1

\section{Line 2}

The results of the correlation between the two-dimensional resistivity section with one-dimensional resistivity $\log$ can be seen in Figure 6 which shows that there is a suitability of the range of resistivity values between the twodimensional resistivity section with onedimensional resistivity $\log$. This onedimensional resistivity log also acts as supporting data so that the interpretations that have been made are better and more accurate. By combining information from the two-dimensional resistivity section and one-dimensional resistivity $\log$, the results of the subsurface model interpretation of the two crossings can be seen in Table 2 . 


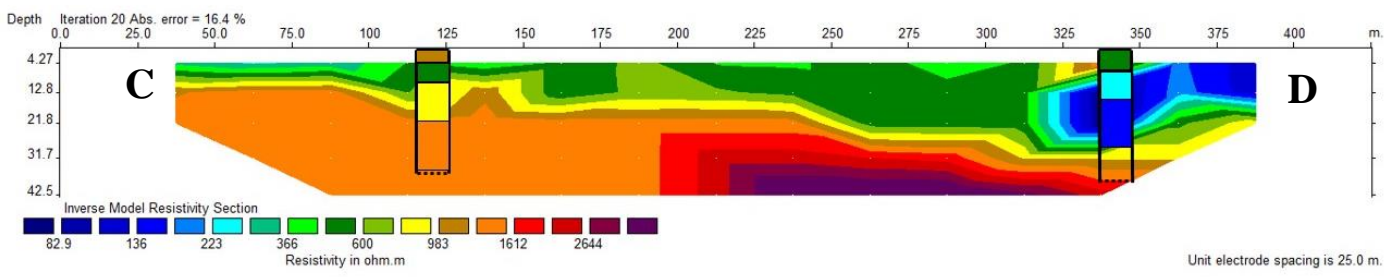

Figure 6. Correlation between line 2 Dipole-dipole with point VES 3 and VES 4 Schlumberger

Table 2. Interpretation of Resistivity values for line 2

\begin{tabular}{|c|l|l|}
\hline Num. & Resistivity Value $\mathbf{( \Omega m})$ & Name of Layer \\
\hline 1. & $82-136$ & Sandstone layer containing fluid \\
\hline 2. & $366-600$ & Sandstone \\
\hline 3. & $916,89-959,95$ & Top Soil \\
\hline 4. & $1612-2644$ & Volcanic stones \\
\hline
\end{tabular}

The resistivity cross section obtained can be given topographic effects so that it can facilitate interpretation. The resistivity crossing on the two paths with topographic effects can be seen in Figure 7. In addition, if the presence of geothermal manifestations is projected on the cross section of the resistivity, one feeding path, the presence of geothermal manifestations is at 350 meters.

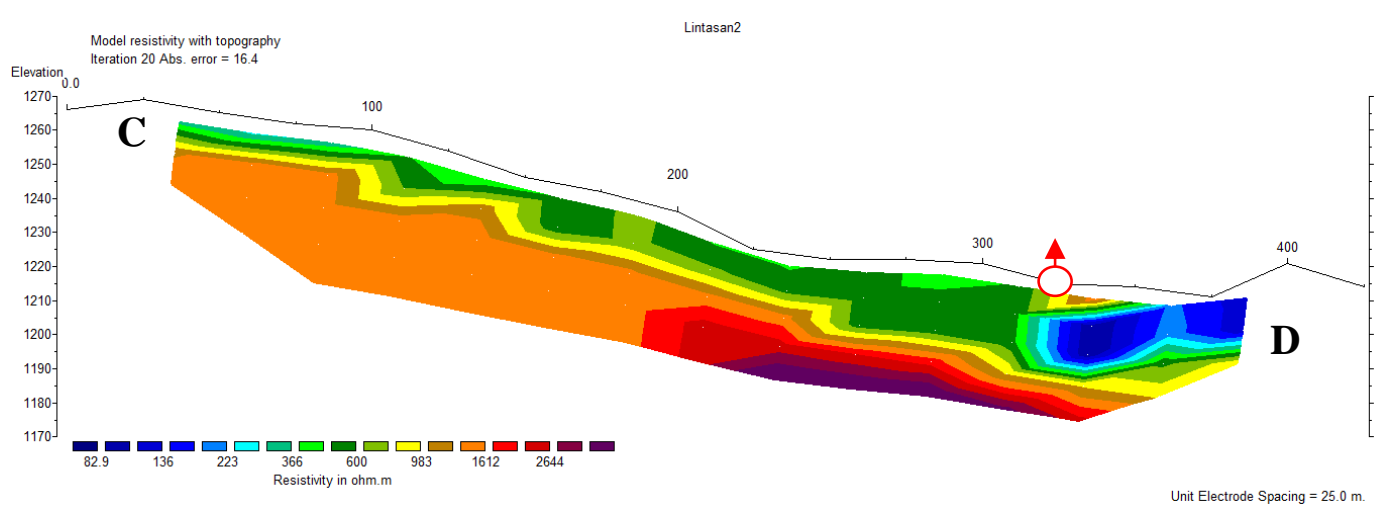

Figure 7. Two-dimensional resistivity cross section with topographic effects on line 2

\section{Estimation of Subsurface Structures of Guci Geothermal Field}

The subsurface structure of the geothermal manifestation area Guci is estimated to consist of layers of top soil, sandstone, volcanic rock, and a weak zone containing fluid. The results of modeling the subsurface structure of the 
geothermal manifestation area of Guci have a layer of volcanic rock which is considered as bedrock or bed rock. These basic rocks are thought to be composed of andesite igneous rocks. According to (Reswara \& Sehah, 2014) the Guci manifestation area is dominated by andesite stones at a depth of $0-5$ kilometers. This is in accordance with the information from the geological map that geothermal areas of these jars are located in the non-biodegradable Slamet volcanic rock area composed of volcanic breccia, lava and tuff (Djuri, et al., 1996). According to (Sutawidjaja, 2009) the study area was in the Bumijawa lahar area which consisted of fresh andesite andesite lumps that had been welded, and was also located in the Gunung Mingkrik lava area which was dominated by pyroxine andesite stones. According to Pratomo (2012) the Guci area which lies to the northwest of the body Slamet volcano has undergone volcanic-tectonic deformation which forms a depression (graben), and based on geological data occupied by deposits Young Slamet Volcano
Basement or bed rock on line one is thought to have experienced disturbance, seen there is an inconsistency in the bedrock which is cut off and filled with sandstone. In the modeling results there is a very low resistivity value, this is thought to be a weak zone filled with fluid. This weak zone is thought to arise due to interference in the area which makes the zone easy to fill with fluid. Disturbances found in the study area are estimated as fault structures that can be seen from the weak zone in the study area containing fluid also coincide with information on fault structures in the Guci area of geological maps. According to (Aminu et al., 2014) the fault zone can also be indicated by a very low resistivity value compared to its surroundings. So that in this one line model it is estimated that there is a fault structure found at around a depth of 20 meters. The description of the subsurface structure of geothermal geothermal manifestation areas can be seen in Figure 8. 


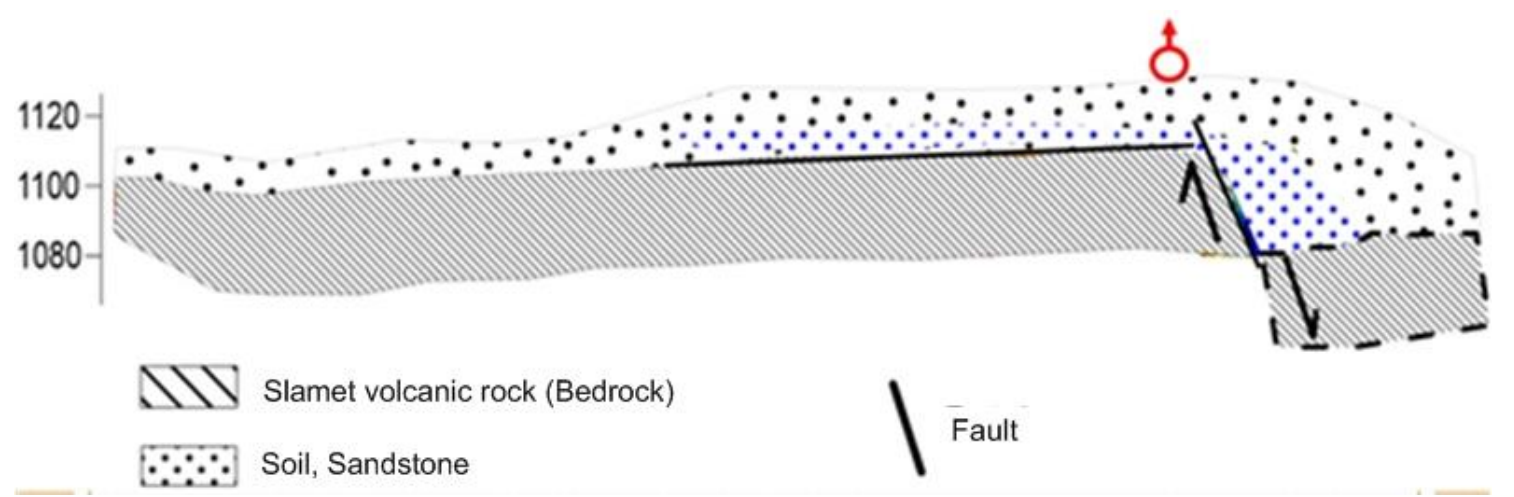

Figure 8. Model of subsurface structure of Guci geothermal

\section{Guci Geothermal System}

Geothermal system is a system which generally consists of several main components, namely heat source, recharge area, reservoir, hood layer, and hot fluid such as If the geological structure allows steam and hot water to flow back to the surface to form geothermal manifestations on the surface (Saptadji, 2009).

Research on geothermal systems in island of Java using geochemical data. This research was conducted in several places in the location of hot springs on the island of Java, one of which is a hot spring located in Guci, Tegal district, Central Java. The research results was found that the Guci hot springs were Volcano-hosted or sourced from a volcano, namely Slamet volcano (Purnomo \& Pichler, 2014).

Geothermal manifestations on the surface can be in upflow and outflow areas. This is known by looking at the chemical content found in the geothermal manifestation. According to (Surmayadi, 2014) the geothermal manifestations in the Guci area showed that the manifestations in the jar area were classified as bicarbonate type indicating that the geothermal area of Guci was an outflow area. Manifestations of Geothermal Urns in the form of condensate water and meteoric water (Utama et al., 2012).

The Guci geothermal system in the Slamet volcano foot complex is estimated to be upflow area around the Igir Cowet mountain (Surmayadi, 2014). Whereas in the Guci area is an outflow area. Geothermal manifestations in the Guci area are thought to arise due to a condensation process in which the hot fluid in the reservoir rises upwards and cools and flows through the fracture path following the topography to the Guci area. Previous research also shows that 
the fluid flow in the Guci geothermal field leads from North to South following changes in the topography of the study area (Nadine et al., 2015).

Geothermal manifestations can occur if there are possible geological structures as fluid discharge paths, one of which is a fault structure. This is also expected to cause the emergence of geothermal manifestations in Guci. The emergence of geothermal manifestations in the area of Guci is thought to be due to the existence of a fluid exit in the form of a fault structure. Faults that are in the Guci area based on Geoelectric data are estimated to be normal faults. So by combining the available information it can be estimated that the subsurface model of the geothermal system in the Guci area is as in Figure 9.

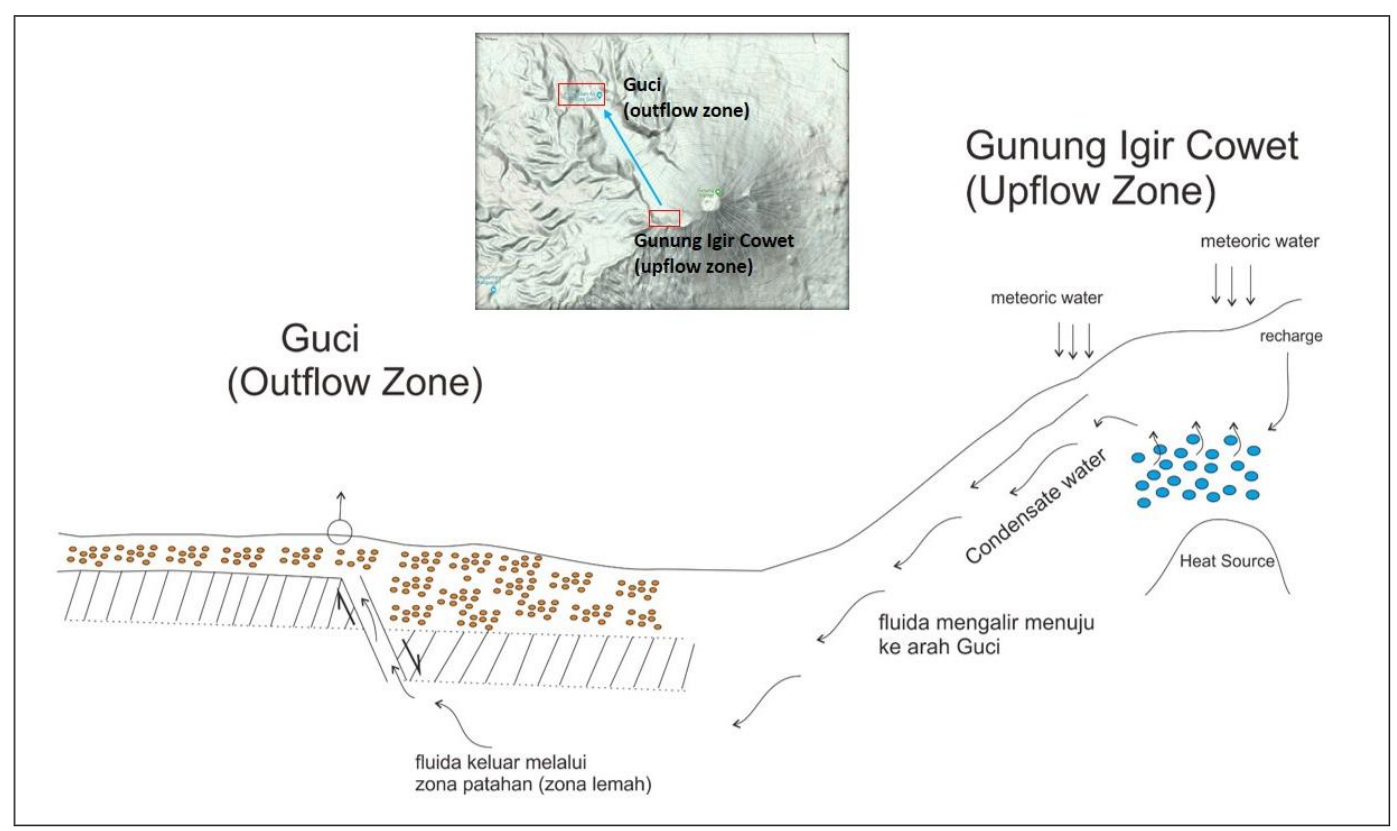

Figure 9. Conceptual model of Guci geothermal system

\section{CONCLUSIONS}

Based on the results of data processing and interpretation, some conclusions can be drawn from this study, including:

1. Based on the value of the resistivity section, the subsurface model of the geothermal manifestation area of the jar consists of layers of top soil, sandstone, andesite stone, and fluid-containing layers.

2. The fluid-containing layer is thought to be related to Guci's geothermal manifestations, and is a fault zone. The fault is estimated to be a normal fault and is around a depth of 20 meters with resistivity 
values ranging from $82-136 \mathrm{ohm}$ meters.

3. Faults that are in the geothermal manifestation area Guci has a role as a way to release hot fluid to the surface to form geothermal manifestations on the surface. The hot fluid here is a geothermal system outflow.

\section{E. REFERENCES}

Aminu, M. B., Akande, T. M., \& Ishola, O. A. (2014). 2D geoelectric imaging of the Uneme-Nekhua fracture zone. International Journal of Geophysics, 2014. https://doi.org/10.1155/2014/8428 12

Broto, S., \& Afifah, R. S. (2008). Pengolahan Data Geolistrik Dengan Metode Schlumberger. Undip Teknik Journal, 29(2).

Khalil, M. A., \& Santos, F. A. M. (2013). 2D and 3D resistivity inversion of Schlumberger vertical electrical soundings in Wadi El Natrun, Egypt: A case study. Journal of Applied Geophysics, 89, 116-124. https://doi.org/10.1016/j.jappgeo.2 012.11.014

Nadine, V., Supriyadi, \& Suharto, L. (2015). Penentuan Arah Fluida Panas Bawah Permukaan Di Obyek Wisata Guci Menggunakan
Metode Self Potential. Unnes Physics Journal, 4(2).

Purnomo, B. J., \& Pichler, T. (2014). Geothermal systems on the island of Java, Indonesia. Journal of Volcanology and Geothermal Research, 285, 47-59. https://doi.org/10.1016/j.jvolgeore s.2014.08.004

Reswara, A., \& Sehah, P. A. (2014). Pendugaan Lapisan Reservoir Panas Bumi Di Kawasan Gunungapi Slamet Dengan Memanfaatkan Data Anomali Medan Gravitasi Citra Satelit. Berkala Fisika, 17(2), 45-54.

Saptadji, N. M. (2009). Karakterisasi Reservoir Panas Bumi. Bandung: Institut Teknologi Bandung, Juli, 6-17.

Surmayadi, M. (2014). Geokimia Panas Bumi Gunungapi Slamet Jawa Tengah. Seminar Nasional Fakultas Teknik Geologi, Universitas Padjadjaran, 163183.

Sutawidjaja, I. (2009). Cinder cones of Mount Slamet, Central Java, Indonesia. Indonesian Journal on Geoscience, 4(1), 57-75. https://doi.org/10.17014/ijog.vol4 no1.20096

Utama, A. P., Dwinanto, A., Situmorang, J., Hikmi, M., \& Irsamukhti, R. (2012). Green Field Geothermal Systems in Java, Indonesia. ITB Geothermal Workshop 2012. 